\title{
ASSESSMENT OF TISSUE PERFUSION DURING CARDIOPULMONARY BYPASS
}

\author{
Nora Porìte* Eva Striḳe*, Mihails Bekers-Ančipolovskis*, Larisa Semčenko*, \\ Inguna Krustina*a*, and Pēteris Stradiṇš ${ }^{* *}$ \\ * Department of Anaesthesiology and Cardiac Surgery ICU, Pauls Stradiṇš Clinical University Hospital, \\ Pilsoṇu iela 13, Rīga, LV-1002, LATVIA; \\ e-mail: nora.porite@gmail.com \\ ** Department of Cardiac Surgery, Pauls Stradinš Clinical University Hospital, Pilsoṇu iela 13, Rīga, LV-1002, LATVIA
}

Communicated by Ludmila Vīksna

\begin{abstract}
Cardiopulmonary bypass (CPB) remains essential for all valvular operations and the vast majority of coronary bypass surgeries. Inadequate CPB results in tissue underperfusion, activation of anaerobic metabolism and increased lactate production. The goal of the study was to determine the factors influencing oxygen delivery to and consumption in tissue. Fifty-six patients (41 male and 14 female patients of 27 to 84 years of age) scheduled to undergo cardiac surgery with CPB were enrolled in this prospective study. No operation-based selection was applied. The following data have been collected and analysed: demographics, preoperative cardiovascular profile. Arterial and venous blood gas tests, including blood glucose and lactate concentrations were obtained. We have assessed $\mathrm{DO}_{2}\left(\mathrm{~mL} / \mathrm{min} / \mathrm{m}^{2}\right)$ and $\mathrm{VO}_{2}\left(\mathrm{~mL} / \mathrm{min} / \mathrm{m}^{2}\right)$, venous oxygen content $\left(\mathrm{CvO}_{2}\right)$ $(\mathrm{mL} / \mathrm{dL})$, arterial oxygen content $\left(\mathrm{CaO}_{2}\right)(\mathrm{mL} / \mathrm{dL})$ calculated according to standard equations based on haemoglobin concentration and saturation in arterial blood, cardiac output or pump flow. The main factors of organ dysoxia during CPB are the haemodilution degree and low peripheral oxygen delivery $\left(\mathrm{DO}_{2}\right)$. Our study confirmed that hematocrit on pump and systemic flow rate determine the amount of oxygen delivery to the body, i.e. $\mathrm{DO}_{2}$ decrease is correlated with decrease of both hematocrit $(\mathrm{Ht})$ and pump flow.
\end{abstract}

Key words: cardiopulmonary bypass, peripheral oxygen delivery, arterial oxygen content, venous oxygen content, lactate.

\section{INTRODUCTION}

Over the past 50 years, extracorporeal circulation has evolved into a remarkably safe means of providing systemic perfusion during open heart surgery. A greater understanding has been gained of its adverse effects at the molecular and biochemical levels on organ system function and patient recovery from surgery. Although cardiopulmonary bypass (CPB) remains essential for all valvular operations, the vast majority of coronary bypass surgeries is still performed with CPB.

The mean age and risk profile of patients reffered for cardiac surgery is constantly rising. Surgeons are now inclined to accept high risk patients because interventional cardiology provides less invasive alternatives for an overlapping patient cohort.

During CPB intravascular filling may be disturbed leading to hypotension. Tissue hypoxia in patients during CPB may be induced by low blood pressure or by insufficient tissue perfusion due to limited pump flow (Hensley et al., 2008). An inadequate perfusion during $\mathrm{CPB}$ results in the activa- tion of anaerobic metabolism in the underperfused organs. Energy production is partially supplied by anaerobic glycolysis. As a result, lactate production increases. The main factors leading to a possible organ dysoxia during CPB are the haemodilution degree (Habib et al., 2003; Swaminathan et al., 2003) and a low peripheral oxygen delivery $\left(\mathrm{DO}_{2}\right)$ (Ranucci et al., 2005). $\mathrm{DO}_{2}$ is the product of cardiac output and the arterial oxygen content. The concept of critical $\mathrm{DO}_{2}$ is based on the assumption that when a patient is perfused below the critical value, the oxygen consumption $\left(\mathrm{VO}_{2}\right)$ becomes dependent on the $\mathrm{DO}_{2}$ (Pinsky, 1994). This state is characterised by a $\mathrm{VO}_{2}$ and $\mathrm{DO}_{2}$ dependency and the development of tissue hypoxia.

There are only a few methods to measure perfusion in the clinical setting. Oxygen consumption $\left(\mathrm{VO}_{2}\right)$ measurement, although not commonly used clinically, but it can be easily calculated from simultaneously measured arterial and venous oxygen contents and pump flow.

Normal oxygen consumption during deep general anaesthesia may be about $90-110 \mathrm{~mL} / \mathrm{min} / \mathrm{m}^{2}$ and falls about $5 \%$ per 
degree centigrade of hypothermia (Cavaliere et al., 1995). Normally $\mathrm{VO}_{2}$ is about $25 \%$ of the $\mathrm{DO}_{2}$ and energy is produced basically through the aerobic mechanism. A decrease in $\mathrm{DO}_{2}$ (extreme haemodilution, low pump flow) is followed by decreased oxygen consumption.

Whenever the $\mathrm{DO}_{2}$ decreases, compensatory mechanisms are usually triggered in order to maintain the $\mathrm{VO}_{2}$ through a higher oxygen extraction (Ranucci, 2006).

The start of CPB rapidly changes the $\mathrm{Ht}, \mathrm{t}^{\circ}$ and blood viscosity values.

At normothermia, if hematocrit falls from 40 to $20 \%$, viscosity will fall about $50 \%$, and at a constant pump flow, the mean arterial pressure (MAP) will fall about 50\%. If arterial pressure during CPB is too low, perfusion of critical vascular beds may be compromised. On the other hand, excessive arterial pressure increases noncoronary collateral flow to the heart during aortic cross-clamping (Hensley et al., 2008).

Blood flow is regulated not only at the level of the central circulation, but also at the regional level and the microcirculatory levels. The flow is determined by the autonomic control of vascular tone and local microvascular responses and to the degree of affinity of the $\mathrm{Hb}$ molecule for oxygen. Systemic vascular resistance (SVR) is modulated by autonomic nervous systemic tone and circulating catecholamine and vasopresors level. These changes are directly related to tissue metabolism.

The goal of study was to identify the factors influencing oxygen delivery and consumption in tissue.

\section{MATERIALS AND METHODS}

The prospective study was performed at Pauls Stradiňš University Hospital within the Latvian Cardiac Surgery Centre (LCSC) from 2008 till 2009. The study was approved by the Pauls Stradiņš University Ethics Committee, and the study design did not include any special intervention, and data collection was based on routine measurements performed during the operation. Fifty-five patients scheduled to undergo cardiac surgery with $\mathrm{CPB}$ were enrolled in this prospective study, including $41(75 \%)$ male and $14(25 \%)$ female patients of 27 to 84 years of age. Average analysed patient age was $64 \pm 11.7$ years. The dominating preoperatively NYHA classes were II and III, average left ventricular ejection fraction (LVEF), was $52 \% \pm 17.1 \%$, with LVEF min $21 \%$ and LVEF max $70 \%$. Fourty-seven percent of all involved patients had a history of myocardial infarction (Table 1).

No operation-based selection was applied. The only exclusion criteria was the presence of an abnormal ( $>2 \mathrm{mMol} / \mathrm{L})$ plasma lactate value before entering CPB.

Fourty-four percent of the patients underwent CABG, 32\% underwent valve replacement, $24 \%$ underwent combined surgery, all of them under CPB. Mean duration of CPB was
PREOPERATIVE CLINICAL CHARACTERISTICS

\begin{tabular}{l|c|c|c|c|r}
\hline \multicolumn{1}{c|}{ Parameter } & No & $\%$ & Mean \pm SD & Min & Max \\
\hline Age $(\mathrm{yr})$ & & & $64.0 \pm 11.7$ & 27.0 & 84.0 \\
BSA $\left(\mathrm{m}^{2}\right)$ & & & $1.9 \pm 0.2$ & 1.5 & 2.4 \\
LVEF (\%) & & & $52.0 \pm 17.1$ & 21.0 & 70.0 \\
History of MI & 26 & 47 & & &
\end{tabular}

SD, Standard Deviation; LVEF, left ventricular ejection fraction; Min, minimal values; Max, maximal values; BSA, body surface area; MI, miocardial infarction.

Table 2

\section{CARDIOPULMONARY BYPASS DATA}

\begin{tabular}{lcccc}
\hline & Mean $\pm \mathrm{SD}$ & Min & Max \\
\hline CPB time $(\mathrm{min})$ & $106.0 \pm 39.0$ & 51.0 & 190.0 \\
X-clamp time $(\mathrm{min})$ & $67.0 \pm 35.6$ & 16.0 & 127.0 \\
Flow rate calculated $\left(\mathrm{L} / \mathrm{min} / \mathrm{m}^{2}\right)$ & $2.4 \pm 2.5$ & 2.0 & 2.7 \\
Actual flow rate $\left(\mathrm{L} / \mathrm{min} / \mathrm{m}^{2}\right)$ & $2.7 \pm 2.7$ & 2.3 & 3.4 \\
Cardioplegia $(\mathrm{mL})$ & $1668.0 \pm 667.0$ & 1000. & 3300.0 \\
Diuresis $(\mathrm{mL} / \mathrm{kg} / \mathrm{h})$ during bypass & 3.8 & 0.0 & 12.0
\end{tabular}

SD, Standard Deviation; Min, minimal values; Max, maximal values; CPB, cardiopulmonary bypass.

$106 \mathrm{~min}$, and mean aortic cross-clamp time was $67 \mathrm{~min}$ (Table 2). Mean calculated flow rate was $2.4 \mathrm{~L} / \mathrm{min} / \mathrm{m}^{2}$. Actual flow rate was $2.71 \mathrm{~L} / \mathrm{min} / \mathrm{m}^{2}$. Mean volume of cardioplegic solution was $1,668 \mathrm{ml}$.

All of the patients received standardised anaesthesia. Invasive haemodynamic monitoring was achieved with a $20-\mathrm{G}$ radial artery catheter, a $20-\mathrm{cm}$ long double-lumen central venous catheter and a fiberoptic PAC (744 HF 7.5F; Edwards Lifesciences, Irvine, CA ) were inserted via the right or left internal jugular vein. CPB was established via a standard median sternotomy, aortic root cannulation and single or double atrial cannulation for venous return. Lowest core temperature during CPB was $35^{\circ} \mathrm{C}$. Antegrade intermittent cold crystalloid cardioplegia was used according to the surgeon's preference. The circuit was primed either with $1,100 \mathrm{~mL}$ of a crystalloid solution (Deltajonin), or 900 $\mathrm{mL}$ crystalloid solution (Deltajonin) and red blood cells, to avoid decrease of $\mathrm{Hb}$ concentration below $20 \%$.

Roller pumps (Stöckert Instruments, Munich, Germany) were used with a hollow fiber D 905 Avant oxygenator (Dideco, Mirandola, Italy). The pump flow was targeted between 2.0 and $2.4 \mathrm{~L} / \mathrm{min} / \mathrm{m}^{2}$. To ensure mean arterial pressure (MAP) above $60 \mathrm{mmHg}$ vasopressor phenylephrine was used. The gas flow was initially set at $60 \%$ oxygen / air ratio and a $1: 2$ flow ratio with the pump flow indexed, and subsequently arranged in order to maintain an arterial oxygen tension $\left(\mathrm{PaO}_{2}\right)>150 \mathrm{mmHg}$ and an arterial carbon dioxide tension $\left(\mathrm{PaCO}_{2}\right)$ between 33 and $38 \mathrm{mmHg}$. Anticoagulation was provided with an initial dose of 300 IU of heparin per kilogram of body weight, injected into a central venous line 10 minutes before the initiation of $\mathrm{CPB}$ with a 
target activated clotting time of 480 seconds. At the end of $\mathrm{CPB}$, heparin was reversed by protamine sulphite at a 1:1 ratio of the loading dose, regardless of the total heparin dosage.

The following preoperative data were collected and analysed: demographics and preoperative cardiovascular profile (Ejection Fraction; New York Heart Association Functional Class, laboratory assays). Arterial and venous blood gas tests, including blood glucose and lactate concentrations were obtained at the start of surgery (T1), at onset of CPB (T2) 20 minutes on CPB (T3), and after termination of CPB (T4). We estimated $\mathrm{DO}_{2}\left(\mathrm{~mL} / \mathrm{min} / \mathrm{m}^{2}\right)$ and $\mathrm{VO}_{2}$ $\left(\mathrm{mL} / \mathrm{min} / \mathrm{m}^{2}\right)$, venous oxygen content $\left(\mathrm{CvO}_{2}\right)(\mathrm{mL} / \mathrm{dL})$, and arterial oxygen content $\left(\mathrm{CaO}_{2}\right)(\mathrm{mL} / \mathrm{dL})$ according to standard equations based on haemoglobin concentration and saturation in arterial blood, cardiac output or pump flow (Marini et al., 2006; Hensley et al., 2008).

Statistical analysis. Difference and shift are the tools to find correlation between mean values. All the data are expressed as mean \pm standard deviation, or as absolute numbers and percentages when appropriate. A $P$ value $<0.05$ was considered significant for all the following statistical tests. The statistical analysis was performed using Statistic 7 General linear modell Annova Analysis. Heterogeneity of variance was avoided by logarithmic transformation.

\section{RESULTS}

Fifty-one percent of the patients required use of vasopressors during CPB (Fig. 1) to maintain stable MAP. MAP at $\mathrm{T} 1$ was $75.4 \pm 15.2 \mathrm{mmHg}$, at T2 $62 \pm 10.8 \mathrm{mmHg}$, at T3 $68.2 \pm 13.8 \mathrm{mmHg}$ and at T4 $71.5 \pm 12.4 \mathrm{mmHg}$. There were no significant changes in glucose and lactate level at any of the times, while use of vasopressors had no statistically significant correlation with lactate level. Nevertheless, vasopressors were mostly used at time $\mathrm{T}_{2}(P<0.05)$, when the lowest Ht value $(23.8 \pm 3.2)$ was observed (Table 3$)$.

Regarding aerobic metabolism the mean supplied $\mathrm{O}_{2}$ amount $\left(\mathrm{paO}_{2}\right)$ at CPB start T 2 was $258.5 \pm 39.1$, after sec-

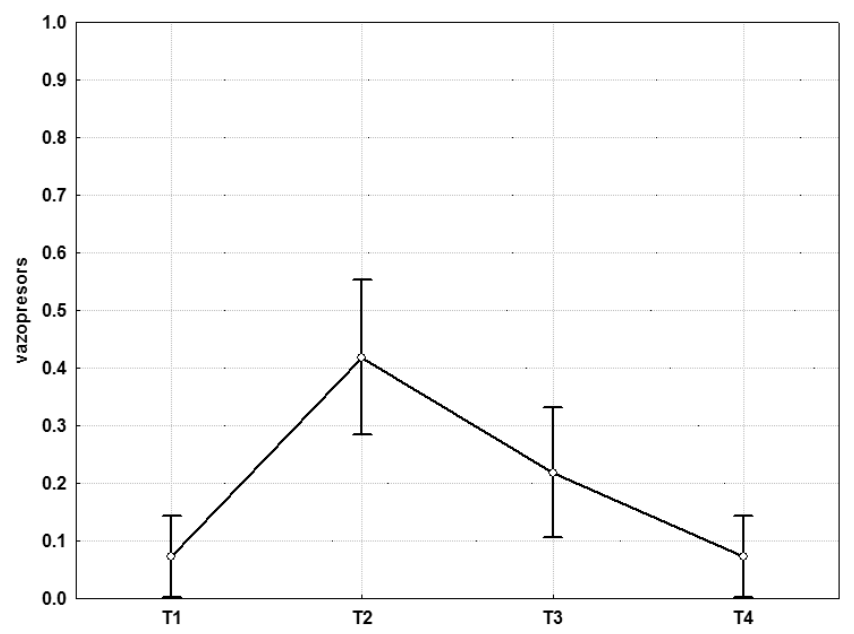

Fig. 1. Use of vasopressors at set times $(P<0.05)$
Table 3

LABORATORY VALUES (mean $\pm \mathrm{SD}$ )

\begin{tabular}{l|c|c|c|c}
\hline & $\mathrm{T}_{1}$ & $\mathrm{~T}_{2}$ & $\mathrm{~T}_{3}$ & $\mathrm{~T}_{4}$ \\
\hline $\mathrm{PaO}_{2}(\mathrm{mmHg})$ & $176.0 \pm 71.0$ & $258.5 \pm 39.1$ & $256.2 \pm 31.9$ & $205.0 \pm 67.0$ \\
$\mathrm{PvO}_{2}(\mathrm{mmHg})$ & $36.0 \pm 5.7$ & $44.9 \pm 9.6$ & $42.2 \pm 8.6$ & $40.0 \pm 7.1$ \\
Glucosae (mMol/L) & $5.9 \pm 1.6$ & $5.3 \pm 1.0$ & $6.0 \pm 1.1$ & $6.3 \pm 1.3$ \\
$\mathrm{Ht}(\%)$ & $38.4 \pm 4.8$ & $23.8 \pm 3.2$ & $27.0 \pm 2.8$ & $28.5 \pm 2.9$ \\
Lactate (mMol/L) & $0.7 \pm 0.3$ & $1.0 \pm 0.3$ & $1.4 \pm 0.7$ & $1.8 \pm 1.1$
\end{tabular}

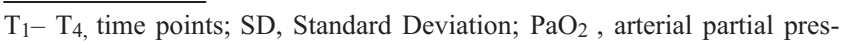
sure of oxygen, $\mathrm{PvO}_{2}$, venous partial pressure of oxygen, $\mathrm{Ht}$, hematocrit

ondary cardioplegia at T3 $256.2 \pm 31.9$, a value is higher than at $\mathrm{T} 1176 \pm 71$, and at T4 $205 \pm 67$ (Table 3)

Oxygen delivery during CPB depends on Ht (Fig. 2a, $P<$ 0.01 ) and $\mathrm{CO}$ (Fig. 2b, $P<0.01$ ), the equivalent of which is the pump flow rate. In our study we found a significant correlation between these values. There was no difference in $\mathrm{DO}_{2}$ at times $\mathrm{T}_{1}-\mathrm{T}_{4}$.

Aerobic metabolism is determined by the amount of $\mathrm{O}_{2}$ molecules, or arterial $\mathrm{O}_{2}$ content, which affects tissue metabolism (Table 4). In our study we found a close correlation between $\mathrm{CaO}_{2}, \mathrm{CvO}_{2}$, and serum concentration of lactate. A decrease of arterial $\mathrm{O}_{2}$ capacity $\mathrm{CaO}_{2}$ below 16
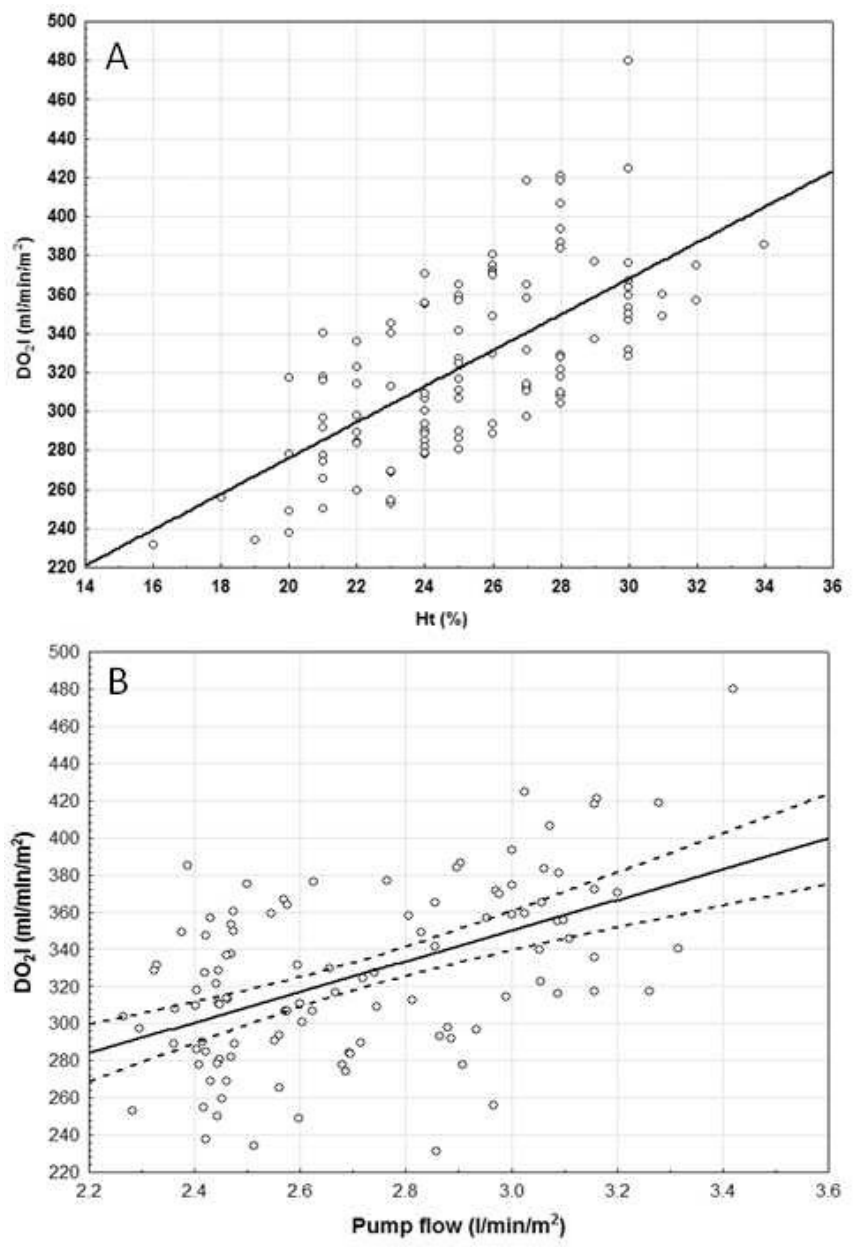

Fig. 2. Relationship of $\mathrm{DO}_{2}$ with $\mathrm{Ht}$ and $\mathrm{CPB}$ flow rate (pump flow). $\mathbf{A}: \mathrm{r}^{2}$ $=0.4617, \mathrm{r}=0.6795, P<0.01 ; \mathbf{B}: \mathrm{r}^{2}=0.2640, \mathrm{r}=0.5139, P<0.01$. 
DERIVED VALUES (mean $\pm \mathrm{SD})$

\begin{tabular}{l|c|c|c|c}
\hline & $\mathrm{T}_{1}$ & $\mathrm{~T}_{2}$ & $\mathrm{~T}_{3}$ & $\mathrm{~T}_{4}$ \\
\hline $\mathrm{VO}_{2} \mathrm{I}\left(\mathrm{mL} / \mathrm{min} / \mathrm{m}^{2}\right)$ & $108.4 \pm 29.0$ & $72.8 \pm 23.9$ & $84.9 \pm 24$ & $125.0 \pm 37.0$ \\
$\mathrm{DO}_{2} \mathrm{I}\left(\mathrm{mL} / \mathrm{min} / \mathrm{m}^{2}\right)$ & $344.2 \pm 92.0$ & $316.0 \pm 48.6$ & $335.6 \pm 42.1$ & $384.0 \pm 85.0$ \\
$\mathrm{CaO}_{2}(\mathrm{~mL} / \mathrm{dL})$ & $17.5 \pm 2.2$ & $11.4 \pm 1.4$ & $12.8 \pm 1.3$ & $13.2 \pm 1.2$ \\
$\mathrm{CvO}_{2}(\mathrm{~mL} / \mathrm{dL})$ & $11.9 \pm 2.0$ & $8.8 \pm 1.4$ & $9.5 \pm 1.6$ & $8.9 \pm 1.3$
\end{tabular}

$\mathrm{VO}_{2} \mathrm{I}$, oxygen consumtion indexed; $\mathrm{DO}_{2} \mathrm{I}$, oxygen delivery indexed; $\mathrm{CaO}_{2}$, arterial oxygen content; $\mathrm{CvO}_{2}$, venous oxygen content.
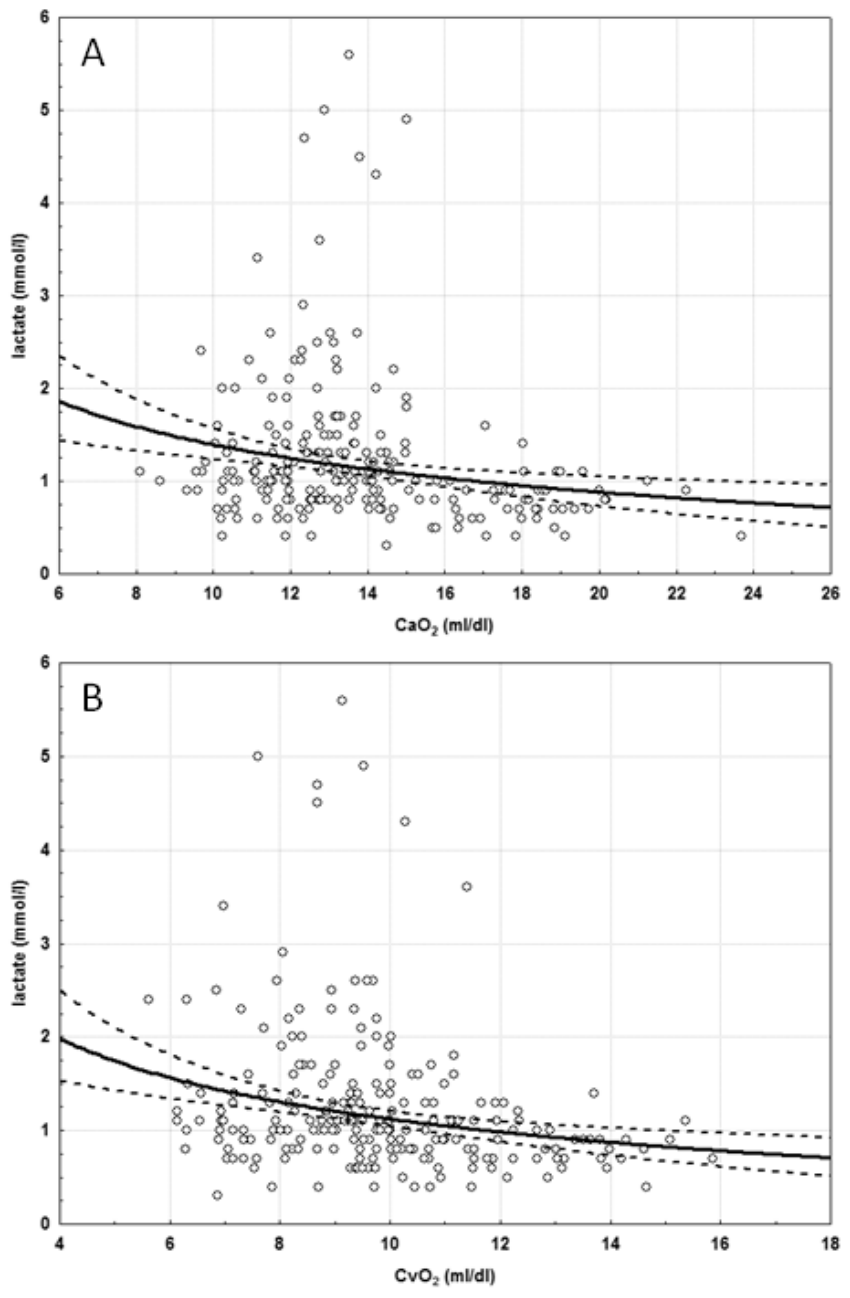

Fig. 3. Impact of $\mathrm{CaO}_{2}$ and $\mathrm{CvO}_{2}$ on serum lactate concentration during CPB. A: $\mathrm{r}^{2}=0.0564, \mathrm{r}=0.237, P<0.05 ; \mathbf{B}: \mathrm{r}^{2}=0.0713, \mathrm{r}=0.267, P<$ 0.05 .

$\mathrm{ml} / \mathrm{dL}$ (Fig. 3a, $P<0.05$ ) and venous $\mathrm{O}_{2}$ capacity below 10 $\mathrm{ml} / \mathrm{dL}$ (Fig. 3b, $P<0.05$ ) resulted in a considerable increase of serum lactate concentration. Despite constant $\mathrm{O}_{2}$ supply we observed different oxygen consumption. The lowest oxygen consumption per square meter of body surface area of patient $\left(\mathrm{VO}_{2} \mathrm{I}\right)$ was observed at time $\mathrm{T}_{2}, 72.8 \pm$ $23.9 \mathrm{ml} / \mathrm{min} / \mathrm{m}^{2}$, while the highest was seen at $\mathrm{T}_{4}$ timepoint, $125 \pm 37 \mathrm{ml} / \mathrm{min} / \mathrm{m}^{2}$ (Table 4).

VO2I consumption at all of the times was significantly influenced by age of patient $(P<0.05)$, and was lower during CPB than before and after CPB (see Fig. 4).

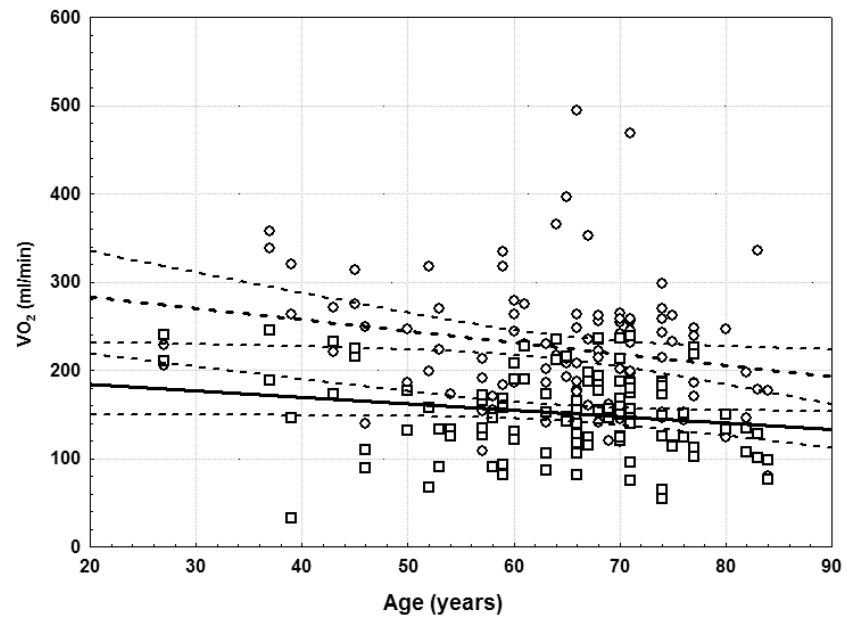

Fig. 4. $\mathrm{O}_{2}$ consumption depending on the age of the patient. $\mathrm{r}^{2}=0.306, \mathrm{r}=$ $0.553, P<0.05$.

Changes in the concentration of lactate, an end-product of glycolysis and glycogenolysis, as well as glyconeogenesis substrate, were used as a marker for organ hypoperfusion, therapy evaluation and prognostic value during CPB. At a Ht value below $20 \%, \mathrm{DO}_{2}$ drops below the critical level $\left(270 \mathrm{ml} / \mathrm{min} / \mathrm{m}^{2}\right)$ (Fig. 2a), which is followed by increased concentration of serum lactate.

A statisticvally significant $(P<0.05)$ increase of serum lactate concentration was observed in patients with prolonged CPB and lower MAP - type A lactatemia (Fig. 5a), and in patients with hyperglycemia, which indicates type B lactatemia.

\section{DISCUSSION}

The main findings of our study are that the hematocrit on pump and systemic flow rate determine oxygen delivery to the body, support the metabolic needs of the various organs and provide appropriate tissue perfusion. $\mathrm{A} \mathrm{DO}_{2}$ decrease was associated with a decrease of both $\mathrm{Ht}$ and pump flow. In the literature the relationship between the lowest hematocrit $(\mathrm{Ht})$ value during $\mathrm{CPB}$ and inadequate tissue perfusion, low cardiac output state and inhospital mortality has been pointed out (Fang et al., 1997).

Haemodilution from the pump prime commonly reduces oxygen delivery by $25 \%$ (Gravlee et al., 2007) and leads to a reduced oxygen transport capacity and decreased systemic vascular resistance. The extremes of haemodilution substantially reduce oncotic presure and increase fluid requirements. This can exacerbate the systemic inflammatory response and capillary leak, causing substantial tissue edema. Changes in $\mathrm{Ht}$ and $\mathrm{t}^{\circ}$ are followed by blood viscosity changes. The lowest haemodilution value in our study was observed just after CPB initiation and crystalloid cardioplegia infusion. At this stage the highest vasopressor infusion rate was necessary to maintain mean arterial pressure. Haemodilution, accepted by current CPB management guidelines, may contribute to postoperative organ dysfunc- 

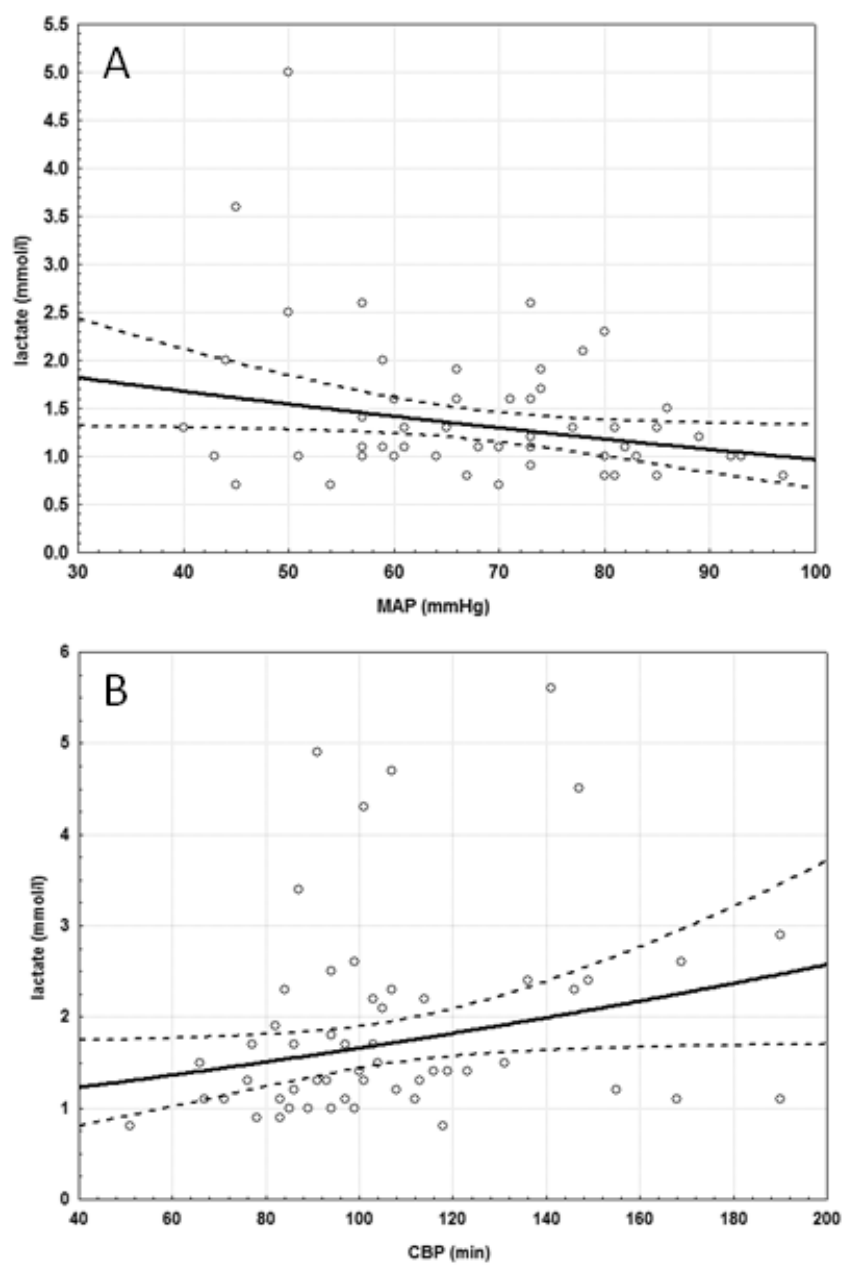

Fig. 5. Type A lactatemia - lactate concentration depending on MAP and CPB duration. A: $\mathrm{r}^{2}=0.0778, \mathrm{r}=0.279, P<0.05 ; \mathbf{B}: \mathrm{r}^{2}=0.0750, \mathrm{r}=$ $0.274, P<0.05$.

tion. Recent observations have pointed out disadvantages of low values of Ht during CPB. De Foe and colleagues found a significant association between low $\mathrm{Ht}$ and return to bypass after attempted separation and described a need for intraaortic balloon pumping (IABP) during or after surgery (DeFoe et al., 2001). Fang et al. considered the lowest Ht on CPB to be an independent risk factor for postoperative low cardiac output and hospital mortality (Fang et al., 1997). A correlation between haemodilution and acute renal failure (ARF) was also confirmed by Swaminathan et al. in 2003 and Ranucci et al. in 2005. The critical Ht value of less than $23 \%$ to $26 \%$ significantly increased the risk of ARF, however, in our study the critical Ht value was $20 \%$.

Ht value during CPB is only one of the two determinants of oxygen delivery $\left(\mathrm{DO}_{2}\right)$, the pump flow being the second. Traditionally, the pump flow rate during CPB is based on the body surface area and on the temperature of the patient, according to specific tables. Generaly, it is set betwen 2.0-3.0 L/min $/ \mathrm{m}^{2}$ to provide an adequate oxygen supply to the organs, depending on the perfusion pressure.

As recording of a low $\mathrm{Ht}$ has a poor clinical value, because the only possible (and arguable) countermeasure is blood transfusion, the oxygen delivery $\left(\mathrm{DO}_{2}\right)$ may be modulated by increasing the pump flow. The basic concept for assessing the adequate pump flow should be the $\mathrm{DO}_{2}$.

One of the factors to provide sufficient oxygen supply to tissues is to maintain MAP during CPB. Thus, the best approaches to maintaining MAP during the surgery are considered: to increase pump flow, to increase Ht or to use vasopressors. However, the maximal flow during CPB is limited by venous return from the patient, which is influenced by the height of the operating table above the heart lung machine, placement of and resistance in venous cannulas and lines, blood volume, and venous tone (Hensley et al., 2008). Limiting intraoperative haemodilution should be considered on time, providing blood transfusions when necessary, while keeping in mind transfusion-related risks. Pump flow should be adjusted to $\mathrm{Ht}$ to avoid drop of $\mathrm{DO}_{2}$ below the critical level of $270 \mathrm{~mL} / \mathrm{min} / \mathrm{m}^{2}$. However, setting the pump flow rate above $2.4 \mathrm{~L} / \mathrm{min} / \mathrm{m}^{2}$ does not considerably change MAP and serum lactate concentration.

Poor venous return supposes at first repositioning of venous canulae or vacuum drainage. If this appears unsuccessful, patient should be cooled to decrease $\mathrm{O}_{2}$ consumption.

Demers and coworkers found that a low haemoglobin level during CPB is associated with hyperlactatemia and it is reasonable to interpret this information within the context of a low $\mathrm{DO}_{2}$ during CPB (Demers et al., 2000).

In our study the $\mathrm{VO}_{2}$ and serum lactate concentration did not change depending on $\mathrm{DO}_{2}$, as there was no critical drop of this value at any time, i.e. below $270 \mathrm{~mL} / \mathrm{min} / \mathrm{m}^{2}$. Critical oxygen delivery is that point at which oxygen consumption $\left(\mathrm{VO}_{2}\right)$ starts to fall (becomes flow dependent) and tissue hypoxemia and lactacidosis begins to occur. A subcritical $\mathrm{DO}_{2}$ level (under $270 \mathrm{~mL} / \mathrm{min} / \mathrm{m}^{2}$ ) is unable to guarantee the oxygen demand to various organs, the oxygen consumption $\left(\mathrm{VO}_{2}\right)$ starts decreasing, while blood lactates start increasing (type A hyperlactatemia).

\section{REFERENCES}

Cavaliere, F., Gennari, A., Martinelli, L., Zamparelli, R., Schiavello, R. (1995). The relationship between systemic oxygen uptake and delivery during moderate hypothermic cardiopulmonary bypass: Critical values and effects of vasodilation by hydralazine. Perfusion, 10(5), 315-321.

DeFoe, G.R., Ross, C.S., Olmstead, E.M, Surgenor, S.D., Fillinger, M.P., Groom, R.C., Forest, J.D., Pieroni, J.W., Warren, C.S., Bogosian, M.E., Krumholz, C.F.,Cantwell, C., Clough, R.A., Weldner, P.W., Lahey,S.J., Leavitt, B.J., Marrin, A.A.S., Charlesworth, D.C., Marshall, P., O'Connor, G.T. (2001). Lowest hematocrit on bypass and adverse outcomes associated with coronary artery bypass grafting. Ann. Thorac. Surg., 71(3), 769-776.

Demers, P., Elkouri, S., Martineau, R., Couturier, A., Cartier, R. (2000).Outcome with high blood lactate levels during cardopulmonary bypass in adult cardiac surgery. Ann. Thorac. Surg., 70(6), 2082-2086.

Fang, W.C., Helm, R.E., Krieger, K.H, Rosengart, T.K., DuBois, W.J., Sason, C., Lesser, M.L., Isom, O.W., Gold, J.P. (1997). Impact of minimum hematocrit during cardiopulmonary bypass on mortality in patients undergoing coronary artery surgery. Circulation, 4;96(9 Suppl), II-194-199. 
Gravlee, G., Davis, R.F., Stammers, A.H., Ungerleider, R.M. (2007). Cardiopulmonary Bypass: Principles and Practice. 3rd ed. Philadelphia: Lippincott Williams \& Wilkins. 785 pp.

Habib, R.H., Zacharias, A., Schwann, T.A., Riordan, C.J, Durham,S.J, Shah,A. (2003). Adverse effects of low hematocrit during cardiopulmonary bypass in the adult: Should current practice be changed? J. Thorac. Cardiovasc. Surg., 125, 1438-1450.

Hensley, F.A., Martin, D.E., Gravlee, G.P. (2008). A Practical Approach to Cardiac Anesthesia. 4rd ed. Philadelphia: Lippincott Williams \& Wilkins. 804 pp.

Marini, J.J., Wheeler, A.P. (2006). Critical Care Medicine. 3rd ed. Philadelphia: Lippincott Williams \& Wilkins. 637 pp.
Pinsky, M.R. (1994). Beyond global oxygen supply-demand relations: In search of measures of dysoxia. Intensive Care Med., 20, 1-3.

Ranucci, M., De Toffol, B., Isqro, G., Romitti, F., Conti, D., Vicentini, M. (2006). Hyperlactatemia during cardiopulmonary bypass: Determinants and impact on postoperative outcome. Critical Care, 10, R167 DOI:10.1186/cc5113.

Ranucci, M., Romitti, F., Isgrn,, G., Cotza, M., Brozzi, S., Boncilli,A., Ditta,A. (2005). Oxygen delivery during cardiopulmonary bypass and acute renal failure following coronary operations. Ann. Thorac. Surg., 80, 2213-2220.

Swaminathan, M., Phillips-Bute, B.G., Conlon, P.J., Smith, P.K., Newman, M.F., Stafford-Smith, M. (2003). The association of lowest hematocrit during cardiopulmonary bypass with acute renal injury after coronary artery bypass surgery. Ann. Thorac. Surg., 76(3), 784-792.

Received 11 July 2009

\section{AUDU PERFŪZIJAS NOVĒRTĒ̌̌SANA MĀKSLĪGĀS ASINSRITES LAIKĀ}

Mākslīgā asinsrite (MAR) ir kḷuvusi par neaizvietojamu sastāvdaḷu visās vārstuḷu operācijās un lielākajā daḷā aortas-koronāras šuntēšanas operāciju. Neadekvāta MAR izraisa audu hipoperfūziju, anaeroba metabolisma akitivāciju un palielina laktātu produkciju. Darba mērkis bija noteikt faktorus, kas ietekmē skābekḷa piegādi un patēriṇu audos. Pētījums bija prospektīvs, un tajā tika iekḷauti 56 pacienti (41 vīrietis un 14 sievietes) vecumā no 27 līdz 84 gadiem, kam MAR tika veiktas sirds operācijas. Pacientu atlase nebija saistīta ar operācijas veidu. Pētījumā tika apkopoti dati un analizēts pacientu demogrāfiskais stāvoklis, preoperatīvais kardiovaskulārais stāvoklis, veiktas arteriālo un venozo asins gāzu analīzes, noteikts glukozes un laktātu līmenis asinīs. Tika noteikta skābekḷa piegāde $\mathrm{DO}_{2}\left(\mathrm{~mL} / \mathrm{min} / \mathrm{m}^{2}\right) \mathrm{un} \mathrm{patēriņš} \mathrm{VO} \mathrm{V}_{2}$ $\left(\mathrm{mL} / \mathrm{min} / \mathrm{m}^{2}\right)$. Izmantojot standarta vienādojumu, aprēḳinājām skābekḷa tilpumu arteriālajās $\left(\mathrm{CaO}_{2}\right)(\mathrm{mL} / \mathrm{dL})$ un venozajās asinīs. Secinājām, ka orgānu disoksijas pamatfaktori MAR laikā ir hemodilūcijas pakāpe un skābekḷa piegāde un patēriņš. Hematokrīta līmenis MAR laikā un asinsrites plūsmas ātrums nosaka skābekḷa piegādes apjomu audiem, t. i., $\mathrm{DO}_{2}$ samazināšanās korelē ar Ht un sūkṇa plūsmas ātruma samazināšanos. 